University of Nebraska - Lincoln

DigitalCommons@University of Nebraska - Lincoln

\title{
Spatial pattern of gas exchange for montane moist meadow species
}

Tony Svejcar

USDA Agricultural Research Service

Gregg M. Riegel

USDA Forest Service

Follow this and additional works at: https://digitalcommons.unl.edu/usdaarsfacpub

Part of the Agricultural Science Commons

Svejcar, Tony and Riegel, Gregg M., "Spatial pattern of gas exchange for montane moist meadow species" (1998). Publications from USDA-ARS / UNL Faculty. 455.

https://digitalcommons.unl.edu/usdaarsfacpub/455

This Article is brought to you for free and open access by the U.S. Department of Agriculture: Agricultural Research Service, Lincoln, Nebraska at DigitalCommons@University of Nebraska - Lincoln. It has been accepted for inclusion in Publications from USDA-ARS / UNL Faculty by an authorized administrator of DigitalCommons@University of Nebraska - Lincoln. 


\title{
Spatial pattern of gas exchange for montane moist meadow species
}

\author{
Svejcar, Tony ${ }^{1 *} \&$ Riegel, Gregg M. ${ }^{2}$
}

\author{
${ }^{1}$ Eastern Oregon Agricultural Research Center, USDA Agricultural Research Service, HC 71, 4.51, Hwy 205, \\ Burns, OR 97720, USA; *Tel. +1 541573 2064; Fax+1 541573 3042; E-mail tony.svejcar@orst.edu; \\ ${ }^{2}$ USDA Forest Service, 1645 NE Hwy 20, Bend, OR 97701, USA
}

\begin{abstract}
Montane moist meadows of western North America are relatively unique in that they are characterized by annual cycles of spring inundation followed by summer drought. Thus, plants adapted to these ecosystems must cope with a wide range of environmental conditions. We compared gas exchange and water relations of upper canopy leaves and leaf area index (LAI) of three dominant montane meadow graminoids growing at both streamside and mid-meadow locations $(2.5$ and $20.0 \mathrm{~m}$, respectively from the stream edge). The two locations were environmentally very different in spite of their close proximity. The water table at the streamside location was ca. $40 \mathrm{~cm}$ closer to the surface compared to the mid-meadow. When averaged over season and species, photosynthetic rates were $12.5 \%(p<0.05)$ higher at the streamside compared to the mid-meadow location, but both conductance and transpiration were similar between locations $(p>0.05)$ The similarity in stomatal response was surprising given that streamside plants had midday xylem potentials that averaged $0.72 \mathrm{MPa}$ less negative (less water-stressed) than that of mid-meadow plants $(p<$ 0.05 ). There was no clear relationship between xylem potential and conductance for the species studied.

Total LAI for the three species combined was nearly three times higher at the streamside compared to mid-meadow location. At the streamside location, Carex nebrascensis had a LAI over twice as high as that of the other species $(p<0.05)$, but there were no significant differences among species $(p>0.05)$ at the mid-meadow location. Carex nebrascensis had a more conservative gas exchange strategy (lower photosynthesis and transpiration) than Juncus balticus or Deschampsia cespitosa, yet developed more leaf area than either of these species. Juncus had higher photosynthesis and transpiration compared to the other species, yet maintained less negative midday xylem potential $(p<0.05)$. Apparently, Juncus balticus maintained a greater supply of moisture to above-ground tissues than the other species, which is probably an indication of higher root length per unit leaf area, or a more efficient water conducting system. The other two species - Carex nebrascensis in particular, maintain relatively conservative gas exchange rates, but under favorable growing conditions (such as occurred at the streamside) can develop high leaf area indices. Wetland species with similar growth forms (graminoid) and distributions can have contrasting patterns of gas exchange and plant water relations.
\end{abstract}

Keywords: Leaf area index; Photosynthesis; Riparian zone; Water stress.

Nomenclature: Hickman (1993).

\section{Introduction}

Availability of water influences the distribution and abundance of virtually all native plant species. A major portion of the earth's vegetation experiences water deficits on a regular basis (Schulze et al. 1987). Much of the ecophysiological research has been focused on adaptation of arid-land plants to water deficits. We have generally assumed that stomatal regulation of gas exchange is not terribly important for plants that grow in wet environments (La Fleur 1988), although it has been suggested that stomatal closure may reduce uptake of toxic ferrous iron in some wetland environments (Jones \& Muthuri 1984). Plants adapted to mesic environments are thought to have relatively low gas exchange rates compared to xeric species (Kubriske \& Abrams 1994). In addition, mesic species may reduce gas exchange more rapidly with the onset of water stress than do xeric species (Webber \& May 1977). How then do mesic species respond to environments with extended periods of water deficit?

The montane meadows of western North America provide a unique opportunity to study plant adaptations to a range of moisture conditions. Montane meadows are spatially and temporally diverse, and have steep environmental gradients (Harte et al. 1995). The hydrologic cycle of montane meadows is heavily influenced by snowpack, thus there can be extreme fluctuations in water table levels over the season and among years (Cooper 1990). The climate of far-western North America is characterized by a summer drought period. Species adapted to montane meadows of this region must cope with complete inundation during spring snow melt, followed rather quickly (sometimes within six weeks) by severe water deficits. The ecophysiology of species adapted to these meadows has received only limited attention (Smith 1985).

We chose to study three graminoid species common to western montane moist meadows. The species represent three functional groups: grasses, sedges, and rushes. Although the ecological requirements of these species are not well defined, the grass is considered characteristic of well drained soils and the rush and sedge of heavy 
textured soils (Ratliff 1985). The specific meadow we studied was bisected by a perennial stream and surrounded by mixed conifer forest. The three species we selected occupied a significant portion of the meadow gradient. Thus, we were able to compare gas exchange and water relations for each of the species growing at both streamside ( $2.5 \mathrm{~m}$ from the stream) and mid-meadow (20 $\mathrm{m}$ from the stream) locations. The streamside is a classic wet meadow type and the mid-meadow is an ecotone between wet and dry meadow vegetation. We hypothesized that: (1) water stress at mid-meadow would reduce gas exchange at that location relative to the streamside, and (2) compared to the rush and sedge, the grass species would exhibit gas exchange and water relations more typical of drought-tolerant species.

\section{Methods}

\section{Study area}

The study was conducted along Big Grizzly Creek in the northern Sierra Nevada (39 $56^{\circ} 00^{\prime \prime}$ N, $120^{\circ} 37^{\prime} 00^{\prime \prime}$ $\mathrm{W}, 1775 \mathrm{~m}$ elevation), about $15 \mathrm{~km} \mathrm{NW}$ of Portola in Plumas County, California. Average annual (1959-1992) precipitation for the area is $902 \mathrm{~mm}$, and yearly precipitation has ranged from 403 to $1637 \mathrm{~mm}$. The precipitation pattern is seasonal, with $85 \%$ occurring between October and April (Fig. 1). Precipitation from August 1 to July 31, was $1050 \mathrm{~mm}$ during 1988-1989; $658 \mathrm{~mm}$ during 1989-1990; and $667 \mathrm{~mm}$ during 1990-1991. The precipitation values were $116 \%, 73 \%$, and $74 \%$, respectively, of the long-term average.

The site could be characterized as a long, narrow, stringer meadow surrounded by mixed conifer forest. Big Grizzly Creek is about $1 \mathrm{~m}$ in width and the associated montane meadow ranges from ca. 150 to $500 \mathrm{~m}$ wide. The forest is dominated by Pinus contorta ssp. murrayana, Abies concolor and Pinus jeffreyi. Within the meadow we selected two locations to study: (1) the streamside, which was $2.5 \mathrm{~m}$ from the stream edge, and (2) the mid-meadow, which was $20 \mathrm{~m}$ from the stream edge. The dominant graminoids near the stream consisted of Carex nebrascensis, Juncus balticus, Deschampsia cespitosa, and Poa pratensis. There were few forbs and no shrubs near the stream's edge (within $5 \mathrm{~m}$ ). The midmeadow was also dominated by the graminoids listed above, but also contained Carex pachystachya, Danthonia pilosa and Hordeum brachyantherum. There were also a variety of forbs at the mid-meadow locations, including Agoseris glauca var. monticola, Aster occidentalis, Epilobium ciliatum ssp. glandulosum, Ranunculus alismifolius var. alismellus, $R$. occidentalis, Stellaria longipes var. longipes, Trifolium longipes, and T. repens. The streamside location was $35.5 \mathrm{~cm}$ lower in elevation than midmeadow. Soils in the area are typic Humaquepts (Blank et al. 1995), and contain high levels of both clay and organic matter.

We selected four $25 \mathrm{~m} \times 100 \mathrm{~m}$ replicate blocks for the study. Each block contained about $25 \mathrm{~m}$ of stream and extended from the stream to the forest edge. The blocks were at least $50 \mathrm{~m}$ apart. Within each block we selected one streamside plot and one mid-meadow plot. The three study species, Juncus balticus, Carex nebrascensis, and Deschampsia cespitosa were present at both locations. All measurements were taken at both streamside and mid-meadow locations in each of the four blocks.

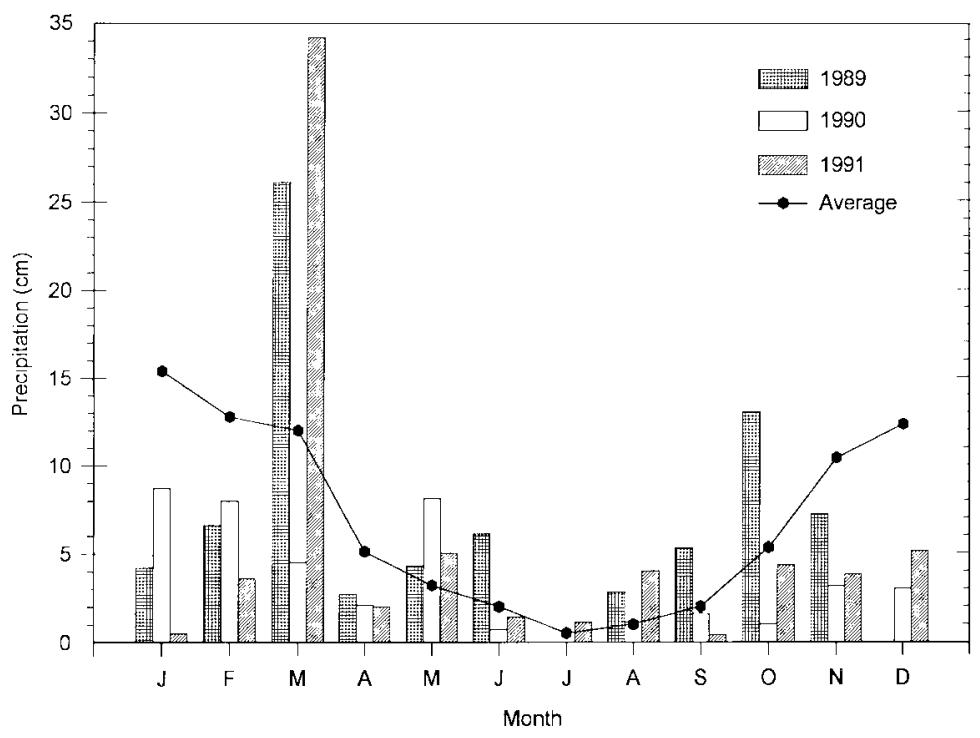

Fig. 1. Monthly precipitation over the course of the study and averaged over the period 1959 to 1992. 


\section{Soil moisture and water table depth}

Soil moisture was measured gravimetrically in 1989. Soil cores were collected at $0-20$ and $20-40 \mathrm{~cm}$ depths, with a 5-cm diameter soil corer. During 1990, soil moisture was measured at 20 and $40 \mathrm{~cm}$ with a neutron probe (Model 503 Campbell Pacific Nuclear Corp., Martinez, California, USA) ${ }^{1}$. Gravimetric measurements from 1990 were used to calibrate the neutron probe. Gravimetric values were converted to volumetric soil moisture using a bulk density multiplication.

Water table depth was measured during 1990 and 1991 using perforated $4 \mathrm{~cm}$ polyvinyl chloride (PVC) tubes. The tubes were buried to a depth of $1.5 \mathrm{~m}$ and water table measurements were taken with a metal tape. Values were expressed as depth from the soil surface.

\section{Gas exchange and xylem water potential}

Photosynthesis, transpiration, and stomatal conductance were measured with an LI-6200 portable photosynthesis system (LI-COR, Inc., Lincoln, Nebraska, USA) equipped with 0.25 -L leaf chamber. All measurements were made on upper canopy leaves exposed to full sunlight during early afternoon. Initial measurements indicated there was no midday stomatal closure for the species studied. Each leaf measurement was conducted over a 30 -sec period. During that time the change in relative humidity and air temperature within the chamber was generally less than $3 \%$ and $1.5^{\circ} \mathrm{C}$, respectively. Ten to 15 minutes after the gas exchange measurements were made the leaves were excised and placed in a pressure chamber (Model 1000, PMS Instrument Company, Corvallis, Oregon, USA) to determine xylem water potential. Leaves were placed on moist paper towels and returned to the laboratory for measurement of leaf area with a LI-3000 area meter (LI-COR, Inc, Lincoln, Nebraska, USA). Within a block, on each measurement date we took one measurement for each of the study species at each location.

Plants to be sampled were selected at random each sampling date. There were five sampling dates from June through September of 1989, and nine sampling dates during May through September of 1990. The day after each sampling, we also measured predawn xylem water potential on one leaf per species/location/block combination.

\footnotetext{
${ }^{1}$ Mention of a tradename does not indicate endorsement by the U.S. Department of Agriculture.
}

\section{Plant biomass and leaf area index}

To estimate above-ground plant biomass, we clipped one $0.89 \mathrm{~m}^{2}$ circular plot to $2 \mathrm{~cm}$ height at each location on July 16, 1990. We separated the plant material into the following categories: Carex nebrascensis, Juncus balticus, Deschampsia cespitosa, all graminoids, and total plant biomass.

Leaf area index (LAI) was determined for each of the three target species on 20 August, 1990. Plants were clipped to ground level in four $20 \mathrm{~cm} \times 20 \mathrm{~cm}$ plots at each location. After harvest, plant material was placed on moist paper towels in zip-lock bags, in an ice chest and transported to the laboratory. Leaves of the study species were excised and scanned for area with an LI3000 area meter. Leaf area index (LAI) is expressed as unit of leaf area per unit of ground area $\left(\mathrm{m}^{2} / \mathrm{m}^{2}\right)$.

\section{Statistical analysis}

The data were analyzed as a randomized complete block design (with four replications), with locations as a split-plot (e.g. Petersen 1985). We could not randomize location within a block. In the case of the physiological parameters and LAI, treatments consisted of locations (streamside and mid-meadow) and species (Carex nebrascensis, Juncus balticus, and Deschampsia cespitosa). Soil moisture and temperature values were analyzed by location. For variables measured over the course of the season there was one analysis in which time was added to the model as a factor, and additionally, each sampling time was analyzed separately to allow interpretation of time interactions. When species effect was significant, we used an LSD procedure to separate means. These analyses were conducted with the Statistical Analysis System, general linear models procedure (Anon. 1988). We also used the general linear model procedure to determine the coefficients of correlation between physiological parameters.

\section{Results}

\section{Soil moisture and water table depth}

Soil moisture was statistically different $(p<0.05)$ among locations on some but not all of the sampling dates (Fig 2). When averaged over the 1989 sampling period, soil moisture at the streamside and mid-meadow locations was $29.5 \%$ and $25.7 \%$, respectively at $20 \mathrm{~cm}$; and $34.2 \%$ and $31.1 \%$, respectively at $40 \mathrm{~cm}$. During 1990, streamside and mid-meadow locations averaged 30.7 and $31.8 \%$, respectively at $20 \mathrm{~cm}$; and 38.0 and $36.9 \%$, respectively at $40 \mathrm{~cm}$. During both years, there 

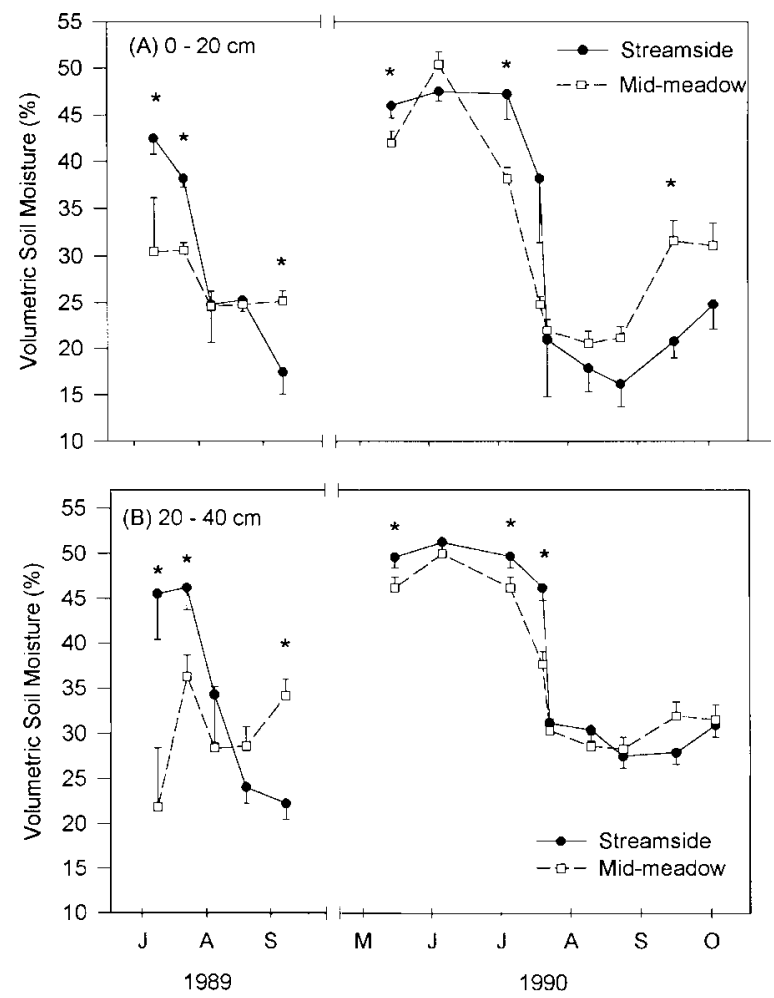

Fig. 2. Soil moisture (\% volumetric) at 20 and $40 \mathrm{~cm}$ for midmeadow and streamside locations. Asterisks indicate significant location differences $(p<0.05)$ for a sampling date.

were highly significant $(p<0.001)$ date by location interactions at the $20 \mathrm{~cm}$ depth. The interaction was highly significant $(p<0.001)$ at the $40 \mathrm{~cm}$ depth during 1989 , but only approached significance $(p=0.059)$ during 1990. The interaction during 1989 can be explained by the fact that soil moisture was higher at the streamside compared to mid-meadow location during July, but declined to similar or even slightly lower values by the end of the sampling period. During 1990, it appears the interaction is a result of a more rapid decline in soil moisture at the mid-meadow compared to streamside location during late June and July.

Water table depth was lower at the mid-meadow compared to the streamside location during most sampling dates (Fig. 3). We included 1991 data to demonstrate that the relationship between the two locations was similar during 1990 and 1991. Unfortunately, we did not have water table tubes installed in time for the 1989 sampling period. Generally, this particular site is covered by snow until early-to-mid spring; during snow melt there is usually surface water at both locations for up to a month (generally part of April and early May). During 1990, water table depth for the two locations began to diverge in April, but a large precipitation event in mid-May increased both water tables to similar levels. After mid-May, the mid-meadow water table declined more rapidly than that at streamside. A similar pattern was evident in 1991, except that after the April peak the water table at both locations declined consistently during the course of the growing season. The midmeadow water table was generally 30 to $50 \mathrm{~cm}$ deeper than the streamside water table after late April.

\section{Gas exchange and xylem water potential}

Both location and species significantly affected predawn xylem potential $\left(\Psi_{p}\right)$ and midday xylem potential $\left(\Psi_{m}\right)$ (Table 1$)$. As expected, $\Psi_{m}$ were more negative at the mid-meadow compared to streamside location (Table 1; Fig. 4). The species ranking for $\Psi_{m}$ was different than we might have predicted from the gas exchange measurements. Although Juncus balticus had higher gas

Table 1. Probability values $(P)$ and means for various physiological parameters over the two-year study. Location significance indicates mid-meadow and streamside measurements were different. Mean separations are presented when species were significantly different. There were no significant location by species interactions.

\begin{tabular}{|c|c|c|c|c|c|c|c|c|c|c|c|c|}
\hline & \multicolumn{2}{|c|}{ Photosynthesis } & \multicolumn{2}{|c|}{ Conductance } & \multicolumn{2}{|c|}{ Transpiration } & \multicolumn{2}{|c|}{ Leaf temperature } & \multicolumn{2}{|c|}{$\begin{array}{c}\text { Midday } \\
\text { xylem potential }\end{array}$} & \multicolumn{2}{|c|}{$\begin{array}{c}\text { Predawn } \\
\text { xylem potential }\end{array}$} \\
\hline & $P$ & $\begin{array}{r}\mu \text { mole } \\
\mathrm{m}^{-2} \mathrm{~s}^{-1} \\
\end{array}$ & $P$ & $\begin{array}{l}\mathrm{mmol} \\
\mathrm{m}^{-2} \mathrm{~s}^{-1}\end{array}$ & $P$ & $\begin{array}{l}\mathrm{mmol} \\
\mathrm{m}^{-2} \mathrm{~s}^{-1}\end{array}$ & $P$ & ${ }^{\circ} \mathrm{C}$ & $P$ & $\mathrm{MPa}$ & $P$ & $\mathrm{MPa}$ \\
\hline Location & 0.04 & & NS & & NS & & 0.008 & & 0.0001 & & 0.0001 & \\
\hline Streamside & & 15.4 & & 357 & & 13.3 & & 30.8 & & -2.45 & & -0.43 \\
\hline Mid-meadow & & 13.7 & & 327 & & 13.4 & & 31.9 & & -3.17 & & -0.67 \\
\hline Species & 0.0001 & & 0.001 & & 0.0001 & & 0.002 & & 0.0001 & & 0.009 & \\
\hline Carex nebrascensis & & $11.0^{\mathrm{c} 1}$ & & $210^{\mathrm{c}}$ & & $8.4^{\mathrm{c}}$ & & $31.1^{\mathrm{b}}$ & & $-2.95^{b}$ & & $-0.46^{\mathrm{a}}$ \\
\hline Juncus balticus & & $19.8^{\mathrm{a}}$ & & $510^{\mathrm{a}}$ & & $19.0^{\mathrm{a}}$ & & $31.0^{\mathrm{b}}$ & & $-2.25^{\mathrm{a}}$ & & $-0.53^{a}$ \\
\hline Deschampsia cespitosa & & $12.9^{\mathrm{b}}$ & & $310^{b}$ & & $13.0^{\mathrm{b}}$ & & $32.0^{\mathrm{a}}$ & & $-3.24^{c}$ & & $-0.65^{b}$ \\
\hline
\end{tabular}


Fig. 3. Watertable depth (relative to soil surface) for the streamside and midmeadow locations. Asterisks indicate significant location differences $(p<0.05)$ on an individual sampling date.
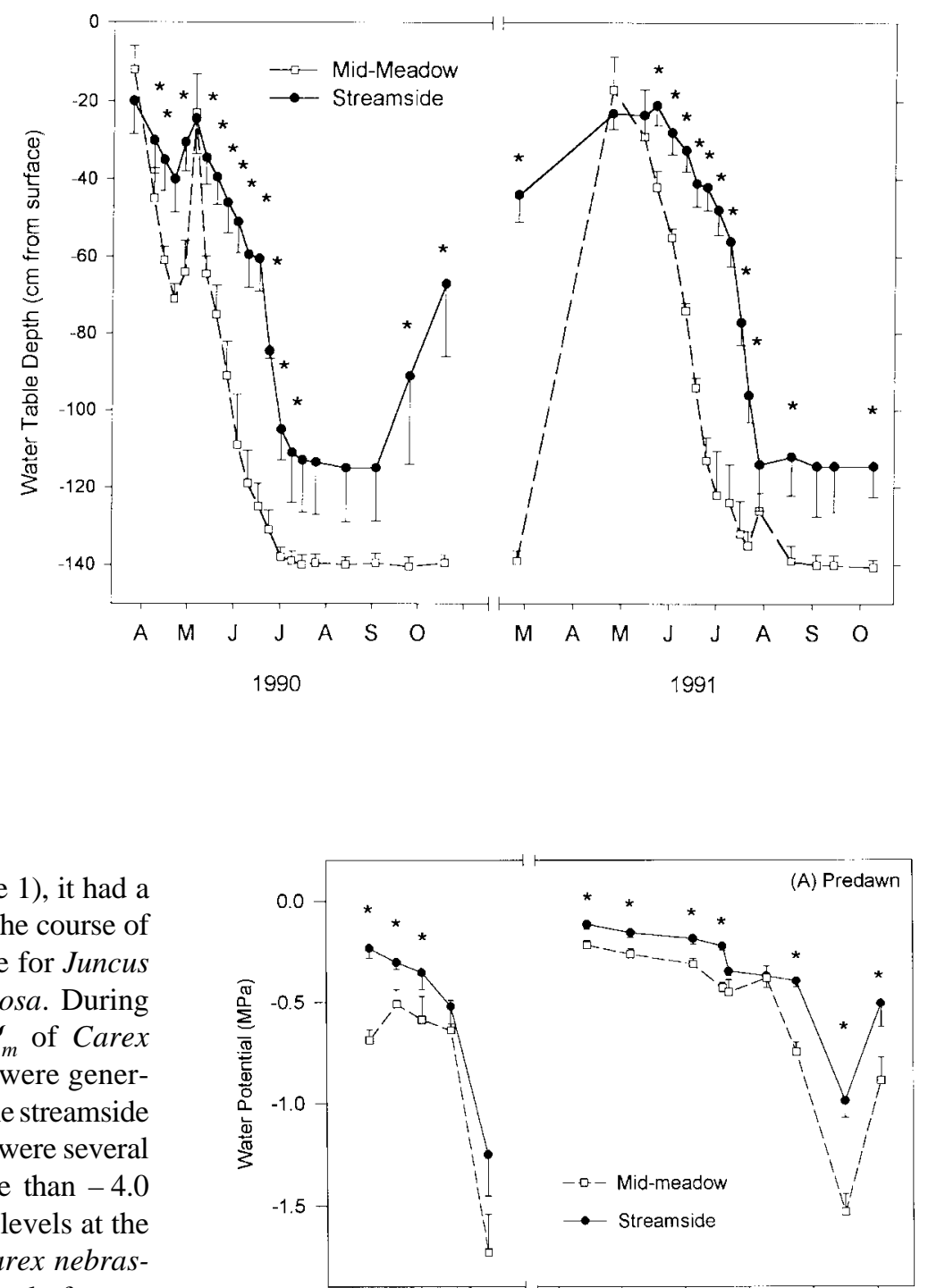

exchange rates than the other species (Table 1), it had a less negative $\Psi_{m}$. In fact, the average over the course of the study was nearly 1.0 MPa less negative for Juncus balticus compared to Deschampsia cespitosa. During the latter part of the growing season, $\Psi_{m}$ of Carex nebrascensis and Deschampsia cespitosa were generally more negative than - 3.0 MPa, even at the streamside location. At the mid-meadow location there were several dates during which $\Psi_{m}$ was more negative than -4.0 MPa. During mid-September of $1990, \Psi_{m}$ levels at the streamside also exceeded -4.0 MPa for Carex nebrascensis and Deschampsia cespitosa. This level of water stress appears rather high for plants growing in a wetland location.

The three riparian species exhibited relatively high rates of photosynthesis, especially at the streamside location (Fig. 5). Analysis of years individually or together yielded the same conclusions, i.e., that both locations and species were statistically different (Table 1). Rates of photosynthesis were higher at the streamside compared to the mid-meadow location, and the species ranking was Juncus balticus $>$ Deschampsia cespitosa > Carex nebrascensis. This same ranking of species held for conductance and transpiration, but locations were not statistically different for either of these variables (Table 1). In general, gas exchange rates tended to be highest in June and July, then declined in August and September.

There was a very low correlation between $\Psi_{m}$ and conductance for most species/ location combinations (Fig 6; Table 3). Most conductance values above $500 \mathrm{mmol}$ $\mathrm{m}^{-2} \mathrm{~s}^{-1}$ occur at $\Psi_{m}$ greater than $-2.7 \mathrm{MPa}$. However,

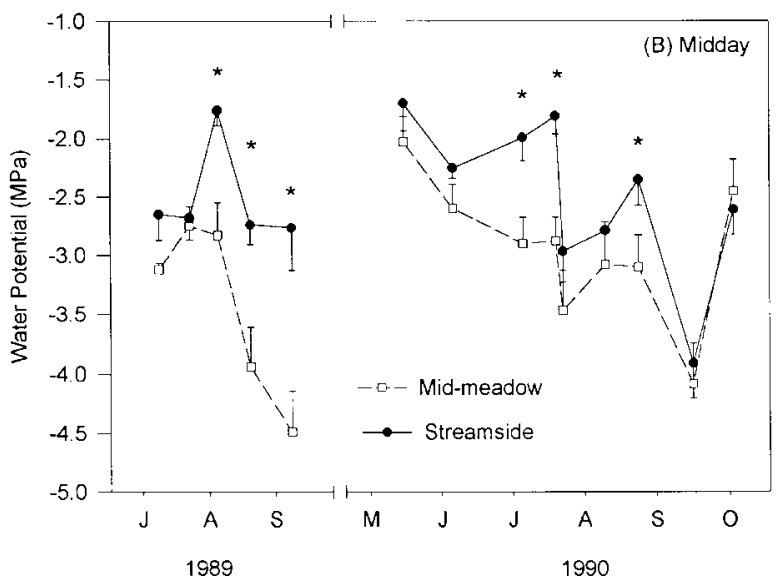

Fig. 4. Seasonal course of predawn (A) and midday (B) xylem potential averaged for the three study species growing at mid-meadow and streamside locations. Asterisks indicate significant location differences $(p<0.05)$ on an individual sampling date. 


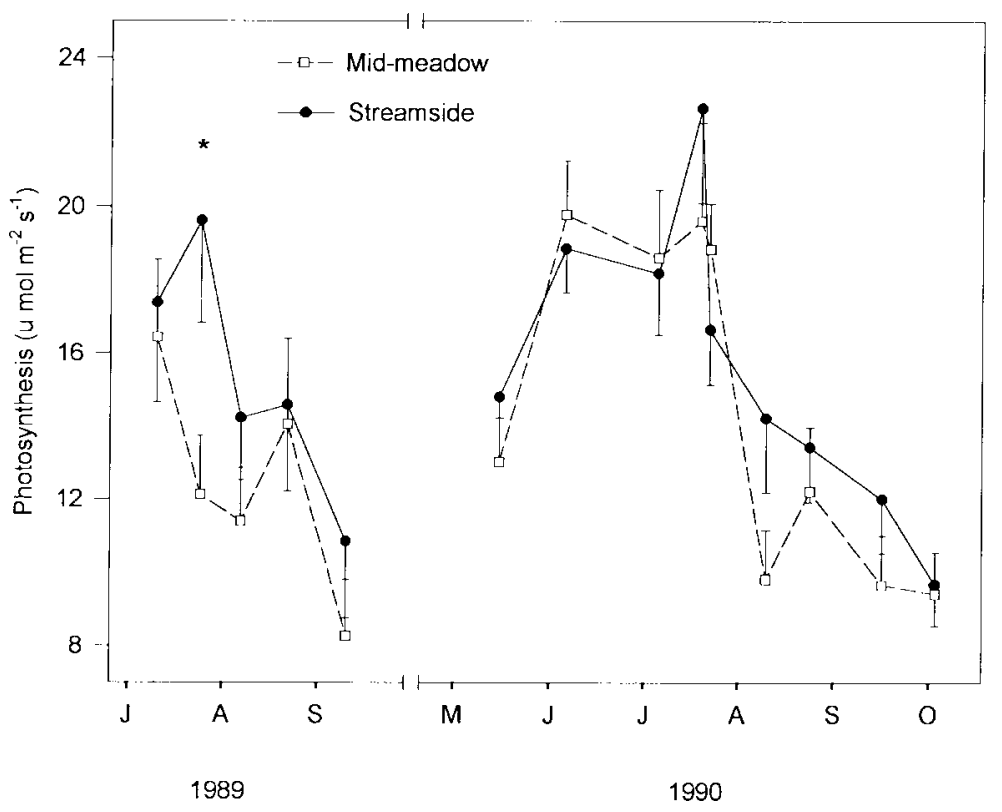

Fig. 5. Seasonal course of photosynthesis averaged for the three study species growing at mid-meadow and streamside locations. Asterisks indicate significant location differences $(p<0.05)$ on an individual sampling date. between $\Psi_{m}$ values of -1.5 and $-2.0 \mathrm{MPa}$, conductance varied from 100 to $1100 \mathrm{mmol} \mathrm{m}^{-2} \mathrm{~s}^{-1}$. Thus, it does not appear that $\Psi_{m}$ holds much potential for predicting gas exchange in these mesic graminoids. There was a more obvious relationship between conductance and photosynthesis (Fig. 7; Table 3). At either streamside or midmeadow locations, the majority of variation in photosynthesis of all three species could be accounted for by conductance values.

\section{Plant biomass and leaf area index}

The streamside location yielded significantly more $(p<0.05)$ plant mass than the mid-meadow location on the July 16, 1990 sampling (475.5 \pm 41.2 and $257.5 \pm$ $31.2 \mathrm{~g} / \mathrm{m}^{2}$, respectively). Leaf area index of the streamside location was nearly three times that of the mid-meadow location (Table 2). The total in Table 2 is the sum of the three study species and is not an actual total for the location, however, the three species dominated plant composition at each location.

\section{Discussion}

The montane moist meadows of western North America are characterized by steep environmental gradients, which makes them a useful setting for studying plant water relations and gas exchange. The wetland setting is also appealing because there is relatively little information on gas exchange of wetland species (La Fleur 1988). The montane meadows of western North American have the added dimension of summer drought, and the species that inhabit this setting must be able to cope with inundation for four to six weeks in the spring followed by three to four months of minimal precipitation (Fig. 1), and clear, sunny conditions.

We selected locations in the meadow that contained the same dominant species, but which represented a wet meadow (streamside) and a transition between wet meadow and dry meadow communities (mid-meadow). The differences between the locations are apparent from the LAI values (Table 2), which were nearly three times higher at streamside compared to mid-meadow. We were surprised that soil moisture was not distinctly higher at the streamside location, and late in the season,

Table 2. Leaf area index of individual species at streamside and mid-meadow locations.

\begin{tabular}{|c|c|c|c|c|}
\hline Location & Carex nebrascensis & Juncus balticus & Deschampsia cespitosa & Total \\
\hline Streamside & 3.45 & 0.98 & 1.21 & 5.64 \\
\hline Mid-meadow & $0.85^{* *}$ & $0.42 * *$ & 0.75 & $2.02 * *$ \\
\hline
\end{tabular}




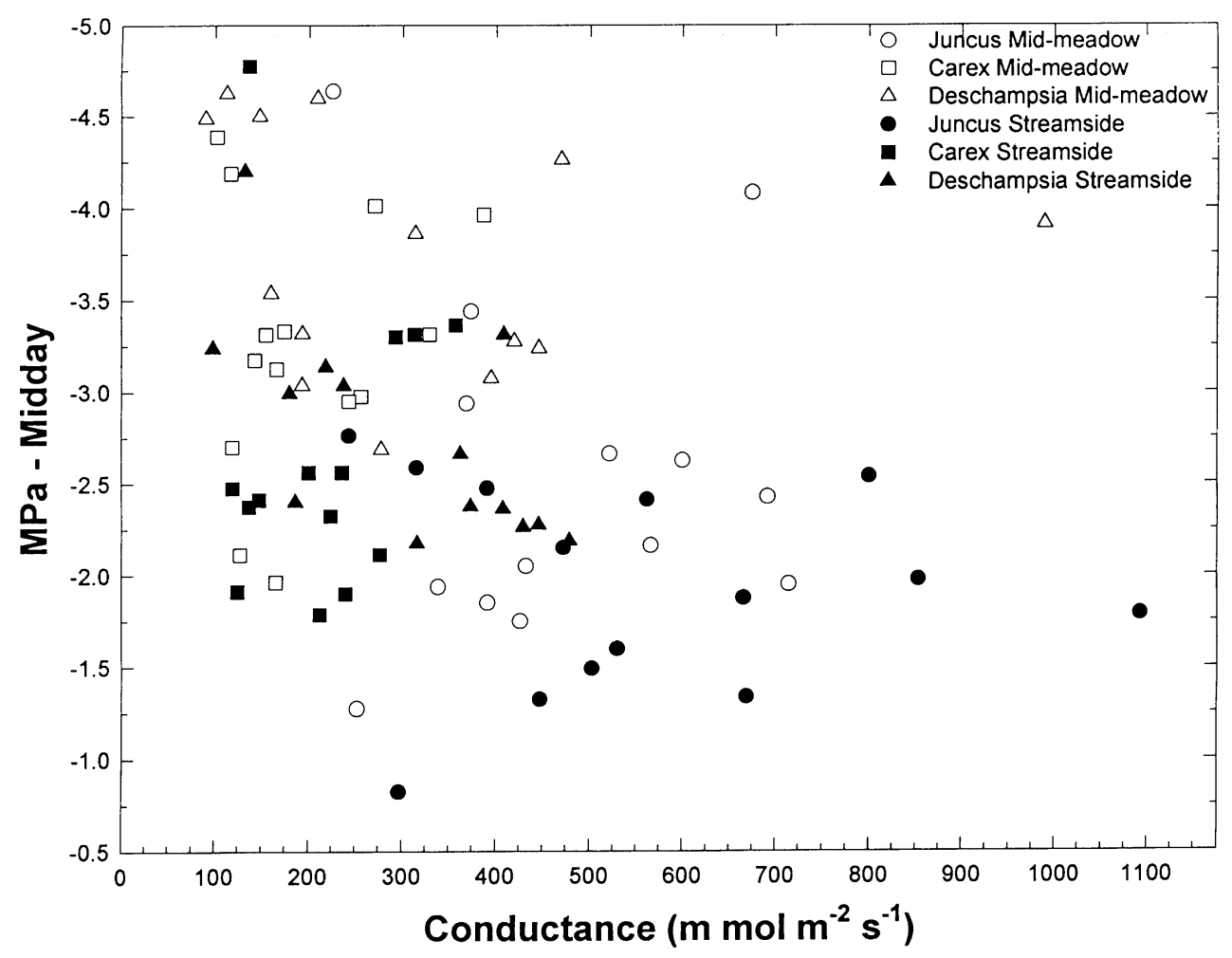

Fig. 6. Relationship between midday xylem potential and conductance for the three study species growing at mid-meadow and streamside locations ( $n=4$ for each point).

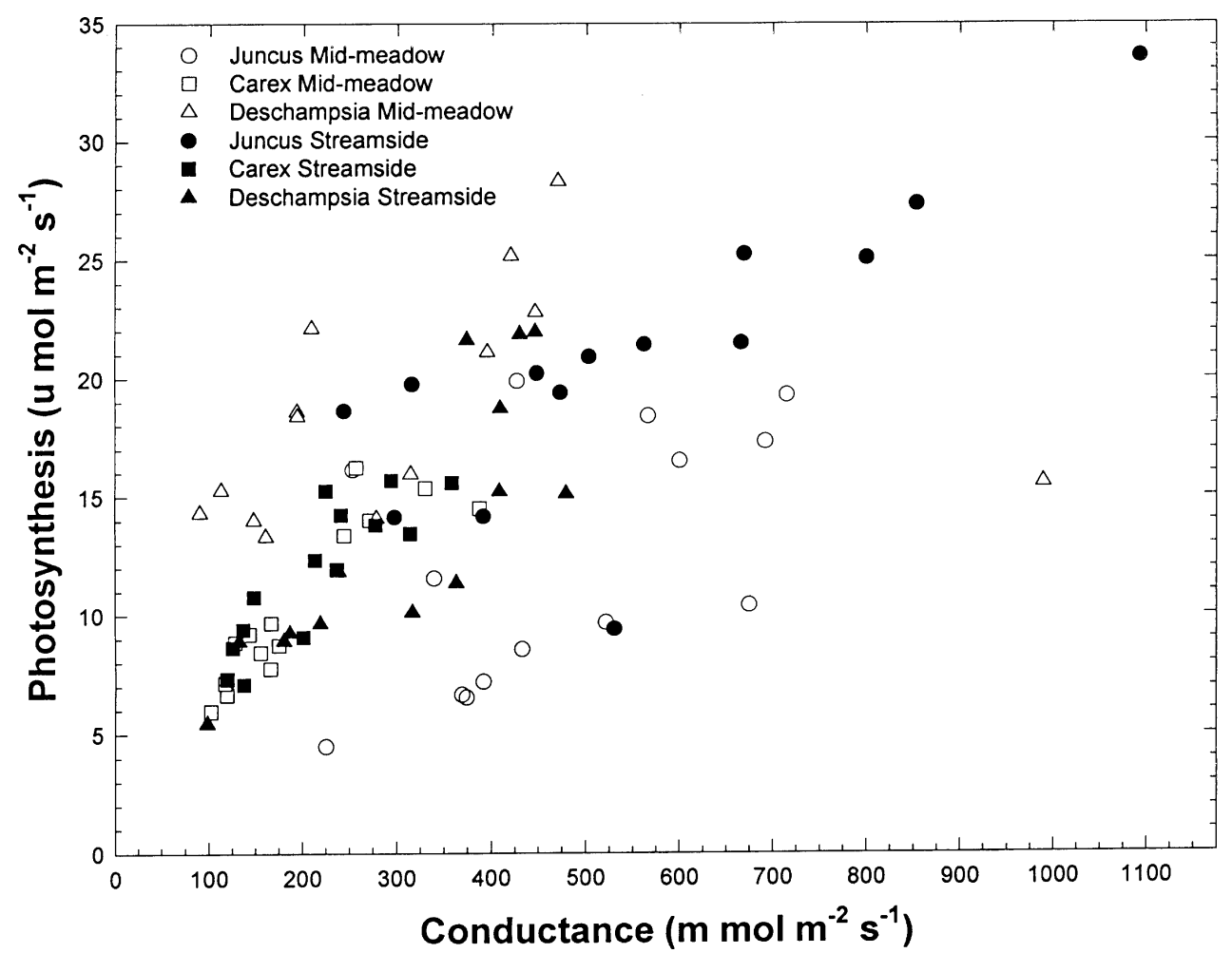

Fig. 7. Relationship between conductance and photosynthesis for the three study species growing at mid-meadow and streamside locations ( $n=4$ for each point). 
Table 3. Coefficients of correlation $(r)$ for the relationship between conductance $(g)$ and photosynthesis $(P S)$ or midday xylem potential $\left(\Psi_{m}\right)$ and conductance $(g)$ for each species/ location combination. All coefficients of correlation were significant $(p<0.01)$ for $g$ vs $P s$, whereas none were significant $(p>0.10)$ for $\Psi_{m}$ vs $g$.

\begin{tabular}{llc}
\hline $\begin{array}{l}\text { Species/Location } \\
\text { Mid-meadow }\end{array}$ & $r(g$ vs $P s)$ & $r\left(\Psi_{m}\right.$ vs $\left.g\right)$ \\
\hline Juncus balticus & 0.67 & 0.06 \\
$\quad$ Carex nebrascensis & 0.88 & 0.18 \\
Deschampsia cespitosa & 0.77 & 0.11 \\
& & \\
Streamside & & \\
Juncus balticus & 0.81 & 0.11 \\
Carex nebrascensis & 0.84 & 0.15 \\
Deschampsia cespitosa & 0.82 & 0.41 \\
\hline
\end{tabular}

was actually higher at mid-meadow than at streamside. The explanation may be that with similar transpiration per unit leaf area (Table 1), and higher LAI, the streamside vegetation created more demand for soil moisture compared to the mid-meadow. Transpiration was measured only on unshaded upper canopy leaves, so we cannot directly calculate canopy water use, but it seems safe to assume that the streamside canopy would have higher overall water use relative to the midmeadow.

Although average soil moisture was similar between the two locations (especially in 1990), plant water potential was generally more negative at the mid-meadow (Table 1, Fig. 4). We suggest that the streamside plants were under less water stress than were mid-meadow plants because of water table depth. With the exception of the early portion of the growing season, the water table was 30 to $60 \mathrm{~cm}$ closer to the surface at the streamside compared to the mid-meadow (Fig. 3). For fine-rooted graminoids, the additional distance to transport water may have reduced growth and increased water stress. Svejcar \& Trent (1995) found that Carex nebrascensis experienced more water stress than Salix lemonii when the two species occupied the same site. These authors suggested that taproots of S. lemonii reached the water table and effectively supplied water to the leaves.

During a drought year, C. nebrascensis was apparently not able to reach the water table and experienced severe water stress $\left(\Psi_{m}<-5.5 \mathrm{MPa}\right)$ (Svejcar \& Trent 1995). Groeneveld \& Or (1994) studied a shrub-herbaceous ecotone underlain by shallow groundwater. They found that the water table in the ecotone fluctuated between 0.8 and $1.2 \mathrm{~m}$; deeper water tables favored shrubs and shallower meadow vegetation. Groundwater may be more reliable than other sources of plant water (Ehleringer \& Dawson 1992).

The three species were characterized by very different physiological profiles. We initially hypothesized that Deschampsia cespitosa would exhibit characteristics more typical of drought tolerant species than would either Juncus balticus or Carex nebrascensis. This assertion is based on the observation that $D$. cespitosa is adapted to well-drained soils, and is considered a facultative wetland species, whereas the other species are adapted to heavier textured soils (Ratliff 1985) and are considered obligate wetland species (Reed 1988). In fact, $D$. cespitosa did maintain lower $\Psi_{m}$ than the other species, which should allow extraction of soil moisture at lower water potentials. In this study all three species grew in soils that were relatively high in clay and not especially well-drained (Blank et al. 1995). If a more negative plant water potential is an adaptation to welldrained (drought-prone) soils, the tendency carries over when $D$. cespitosa grows in heavier soils as well. In spite of the low $\Psi_{m}$,D. cespitosa maintained gas exchange rates that were intermediate to the other two species (Table 1). Of the species we studied, D. cespitosa exhibited the least reduction in leaf area from the streamside to mid-meadow (Table 2).

In many aspects, the most interesting physiological comparison is between the two obligate wetland species, Juncus balticus and Carex nebrascensis. These two species are common not only in montane meadows, but also in a wide range of other wetland settings. $J$. balticus had higher rates of gas exchange than $C$. nebrascensis, yet $\Psi_{\mathrm{m}}$ was consistently less negative for J. balticus (Table 1, Fig 6). It appears that $C$. nebrascensis maintains a steady, but relatively low conductance and $\Psi_{\mathrm{m}}$ declines when water is limiting (thus the large range in $\Psi_{m}$ ). On the other hand, $J$. balticus is capable of high conductance values, and apparently varies stomatal opening to maintain $\Psi_{m}$ within a narrower range. These two different gas exchange strategies help explain the poor correlation between $\Psi_{m}$ and conductance (Table 3 ).

In a subsequent study at the Grizzly Creek site, Seeger (1993) also measured higher photosynthetic rates and lower water stress in J. balticus compared to $C$. nebrascensis. J. balticus may be efficient at moving moisture from the soil into the leaf. This species maintains a high level of conductance relative to the other species studied, yet stomatal water loss does not create the level of leaf water stress we would have expected. The high rates of photosynthesis and low water stress did not translate into a higher LAI for J. balticus compared to the other species (Table 2).

There is limited research on either the growth characteristics or adaptations of the species we studied. We 
know these species tend to have profuse rooting habits (Webber \& May 1977; Manning et al. 1989), however there is no data on above-ground/below-ground allocation patterns or response to environmental factors. The higher photosynthetic rates of Juncus balticus, higher $\Psi_{\mathrm{m}}$, and moderate levels of LAI might lead one to speculate that this species allocates a larger portion of its carbon budget to below-ground structures. A higher root length per unit of leaf area might also help explain how this species maintains high conductance with relatively low plant water stress.

\section{Conclusions}

The montane moist meadows of far western North American are relatively unique in that their annual water cycle includes complete inundation in the spring, followed by summer drought. The transition from inundation to drought can occur rapidly (in some cases, less than six weeks), and the summer drought period can last up to four months. Other wetlands also experience wet and dry cycles, but generally over a longer time frame.

We found that the three dominant graminoids in this system possessed different gas exchange strategies. However, the seasonal trends in gas exchange follow patterns we would expect for upland graminoids in this region. In the upland communities, early season gas exchange is limited by low air and/or soil temperatures and late season gas exchange is limited by soil moisture deficits (Smith \& Nowak 1990). Thus, in upland communities, there is a relatively short period with high rates of gas exchange; this response was also observed for the montane meadow species (Fig. 5). The peak photosynthesis values for the montane meadow species (Fig. 7) are comparable to peak rates measured for upland bunchgrasses of the region (e.g. Anderson \& Toft 1993). The higher leaf area indices and above-ground biomass of the montane meadow graminoids compared to associated upland graminoids are likely a result of: (1) a longer period of peak gas exchange rates, and (2) less of a decline in gas exchange during the second half of the growing season (Fig. 5). Many upland graminoids have very low gas exchange rates by early August and in some years are dormant by mid to late August. Thus, we suggest that the access to the water table during the last half of the growing season is the primary factor that functionally separates the montane meadow from associated upland ecosystems.
Acknowledgements. We thank Jim Trent for assistance with field measurements, Kara Paintner and Jon Bates for conducting the analysis and graphing the data, and Stan Smith and Bill Winner for reviewing earlier versions of the manuscript. We also thank Carol McDonald for word processing the manuscript. The editor and two reviewers for the journal also improved the manuscript considerably.

\section{References}

Anon. 1988. SAS/STAT Users's Guide (Release 6.03) SAS Inst. Inc., Cary, NC.

Anderson, J.E. \& Toft, N.L. 1993. Depletion of soil moisture by two cold-desert bunchgrasses and effects on photosynthetic performance. Great Basin Nat. 53:97-106.

Blank, R.R., Svejcar, T.S. \& Riegel, G.M. 1995. Soil genesis and morphology of a montane meadow in the northern Sierra Nevada range. Soil Sci. 160: 136-152.

Cooper, D.J. 1990. Ecology of wetlands in Big Meadows, Rocky Mountain National Park, Colorado. U.S. Department of Interior, Fish and Wildlife Service, Biological Report 90 (15).

Ehleringer, J.R. \& Dawson, T.E. 1992. Water uptake by plants: perspectives from stable isotope composition. Plant Cell Environ. 15: 1073-1082.

Groeneveld, D.P. \& Or, D. 1994. Water table induced shrubherbaceous ecotone: hydrologic management implications. Water Resour. Bull. 30: 911-920.

Harte, J., Torn, M.S., Change, F.-R., Feifarek, B., Kinzig, A.P., Shaw, R. \& Shen, K. 1995. Global warming and soil microclimate: results from a meadow-warming experiment. Ecol. Appl. 5: 132-150.

Hickman, J.C. 1993. The Jepson manual: higher plants of California. Univ. of California Press, Berkeley, CA.

Jones, M.B. \& Muthuri, F.M. 1984. The diurnal course of plant water potential, stomatal conductance and transpiration in a papyrus (Cyperus papyrus L.) canopy. Oecologia (Berl.) 63: 252-255.

Kubriske, M.E. \& Abrams, M.D. 1994. Ecophysiological analysis of woody species in contrasting temperate communities during wet and dry years. Oecologia (Berl.) 98: 303-312.

La Fleur, P. 1988. Leaf conductance of four species growing in a subarctic marsh. Can. J. Bot. 66: 1367-1375.

Manning, M.E., Swanson, S.R., Svejcar, T. \& Trent, J. 1989. Rooting characteristics of four intermountain meadow communities. J. Range Manage. 42: 309-312.

Petersen, R.G. 1985. Design and analysis of experiments. Marcel Dekker, Inc., New York, NY.

Ratliff, R.D. 1985. Meadows of the Sierra Nevada of California: state of knowledge. USDA Forest Service, General Technical Report PSW-84.

Reed, P.B., Jr. 1988. National list of plant species that occur in wetlands: California. U.S. Department of Interior, Fish and Wildlife Service, Biological Report $88(26,10)$.

Schulze, E.-D., Robichaux, R.H., Grace, J., Rundel, P.W. \& Ehleringer, J.R. 1987. Plant water balance. Bioscience 37: 30-37. 
Seeger, B.L. 1993. Photosynthetic and morphological acclimation of wet meadow graminoids to decreasing soil water availability under natural and glasshouse conditions. MSc. Thesis, University of Nevada, Reno, NV.

Smith, W.K. 1985. Western montane forests. In: Charlot, B.F. \& Mooney, H.A. (eds.) Physiological ecology of North American plant communities, pp. 95-126. Chapman and Hall, New York, NY.

Smith, S.D. \& Nowak, R.S. 1990. Ecophysiology of plants in the intermountain lowlands. In: Osmond, C.B., Pitelka, L.F. \& Hidy, G.M. (eds.) Plant biology of the Basin and Range, pp. 179-242. Springer-Verlag, Berlin.

Svejcar, T.J. \& Trent, J.D. 1995. Gas exchange and water relations of Lemmon's willow and Nebraska sedge. $J$. Range Manage. 48: 121-125.

Webber, P.J. \& May, D.E. 1977. The magnitude and distribution of belowground plant structures in the alpine tundra of Niwot Ridge, Colorado. Arct. Alp. Res. 9: 157-174.

Received 16 October 1996; Revision Received 26 June 1997; Accepted 5 December 1997. 